\title{
Resource utilization patterns of epifauna from mangrove forests with contrasting inputs of local versus imported organic matter
}

\author{
Steven Bouillon ${ }^{1, *}$, Tom Moens ${ }^{2}$, Inge Overmeer ${ }^{1}$, Nico Koedam ${ }^{3}$, Frank Dehairs ${ }^{1}$ \\ ${ }^{1}$ Department of Analytical and Environmental Chemistry, Mangrove Management Group, Vrije Universiteit Brussel, \\ Pleinlaan 2, 1050 Brussels, Belgium \\ ${ }^{2}$ Biology Department, Marine Biology Section, Ghent University, Krijgslaan 281/S8, 9000 Gent, Belgium \\ ${ }^{3}$ Department of General Botany and Nature Management, Mangrove Management Group, Vrije Universiteit Brussel, \\ Pleinlaan 2, 1050 Brussels, Belgium
}

\begin{abstract}
Mangrove epifaunal communities have access to various carbon and nitrogen sources and we hypothesized that the degree of material exchange with the aquatic environment might influence the overall use of different substrates by intertidal communities. Therefore, we analyzed $\mathrm{C}$ and $\mathrm{N}$ stable isotope ratios in primary producers, sediments and 245 samples of epifauna hand-collected from 5 sites in India, Sri Lanka and Kenya (representing estuarine, lagoonal and basin-type mangrove forests). Several patterns emerged from this data set. First, epifaunal communities used a range of available food substrates at all sites studied, including mangrove-derived organic matter, local microphytobenthos and micro-epiflora, as well as imported $\mathrm{C}$ and $\mathrm{N}$ from the aquatic environment (i.e. phytoplankton- and/or seagrass-derived organic matter). Secondly, our data indicate that at sites with significant inputs of aquatic sources, use of mangrove carbon is rather limited on a community basis, whereas in systems with less material exchange with adjacent waters, the relative importance of mangroves is higher. Thus, despite the unquestionable impact some epifaunal species may have on leaf litter dynamics, the dependency of the invertebrate community as a whole on mangrove litter is not ubiquitously large and varies according to the availability of local versus tidally imported sources. Precise quantification of the relative importance of different substrates with $\delta^{13} \mathrm{C}$ and $\delta^{15} \mathrm{~N}$ is, however, not always straightforward due to the multitude of available sources and the overlap in source stable isotope signatures. Micro-epiflora on mangroves trees were remarkably depleted in ${ }^{15} \mathrm{~N}$ in all systems $\left(\delta^{15} \mathrm{~N}\right.$ between -8.2 and $-2.4 \%$ ) and thus form an example where $\delta^{15} \mathrm{~N}$ is a useful source indicator, as low $\delta^{15} \mathrm{~N}$ values of several gastropod species indicated substantial feeding on such epiflora.
\end{abstract}

KEY WORDS: Sesarmid crab · Mollusk · Intertidal $\cdot$ Invertebrate $\cdot$ Foodweb $\cdot$ Stable isotope $\cdot$ Carbon · Nitrogen

Resale or republication not permitted without written consent of the publisher

\section{INTRODUCTION}

Mangrove forests are often a prominent feature of the coastline in the tropics and subtropics, and are increasingly being exploited by humans. A thorough understanding of the ecological functioning and of their interactions with adjacent ecosystems is important in providing a scientific basis for the management and/or restoration of mangroves. Many aspects of car- bon dynamics in mangrove and adjacent ecosystems are still far from understood (e.g. Bouillon et al. 2004), and in view of the various settings in which mangrove forests may occur, it is imperative to obtain data from a range of contrasting mangrove ecosystems rather than generalizing conclusions from any particular site (e.g. Ewel et al. 1998).

Invertebrate communities in intertidal mangrove forests have access to a variety of carbon and nitrogen 
sources: local inputs from mangroves as litterfall or as part of the sediment organic matter pool, microphytobenthos, a variety of epiflora and tidally imported sources such as phytoplankton- or seagrass-derived organic matter. The removal of large amounts of leaf litter by crabs observed in some systems (see Lee 1998) and the fact that some other well-studied mangrove invertebrates (e.g. the gastropod Terebralia palustris) have been observed to feed extensively on mangrove leaves (e.g. Fratini et al. 2000) has nourished the still prevalent view that 'the great majority of the mangrove macrobenthos relies directly on the high production of the mangroves themselves, consuming either leaf litter or detritus composed of decaying leaves' (e.g. Fratini et al. 2000, Ashton 2002). The observation that a significant proportion of leaf production is efficiently removed and/or consumed by some epifaunal species (e.g. Ólafsson et al. 2002) in some mangrove systems, is not necessarily contradictory to the idea that mangrove epifaunal communities as a whole may not depend primarily on mangrove production as a direct food source. Recent results from stable isotope studies (e.g. Christensen et al. 2001, Bouillon et al. 2002, Hsieh et al. 2002) indeed suggest that only a limited number of species may rely substantially on mangrove carbon and that a range of other carbon sources are used by the invertebrate community. Nevertheless, the degree to which such results can be generalized is not known. In particular, mangroves occur in highly variable geomorphological settings, which greatly influence the availability of potential $\mathrm{C}$ and $\mathrm{N}$ sources: where tidal exchange is significant, marine/estuarine sources such as phytoplankton- or seagrass-derived organic matter can be imported, but in low tidal amplitude settings, mangroves are the dominant source of carbon available in the sedimentary pool (Bouillon et al. 2003).

The use of stable isotopes as tracers of the origin and assimilation of organic matter by faunal communities has become widespread, and is based on the assumptions that (1) different sources (may) have different $\delta^{13} \mathrm{C}$ and $\delta^{15} \mathrm{~N}$ signatures, and (2) assimilation by con- sumers results in little fractionation in the case of ${ }^{13} \mathrm{C}$ (i.e. consumer $\delta^{13} \mathrm{C}$ values are close to those of their diet, with a slight enrichment typically between 0 and $2 \%$ ), and somewhat higher for ${ }^{15} \mathrm{~N}$ (a value of $~ 3 \%$ is often cited, but the actual degree of fractionation varies as a function of taxonomy, food quality and environmental factors, see e.g. Vanderklift \& Ponsard 2003 for a recent review).

We hypothesized that the dependency of the epifaunal community on mangrove-derived organic matter would vary across different environmental settings and that such differences would be related to the relative availability of different potential sources. Therefore, we compared data on resource utilization patterns (as evident from $\delta^{13} \mathrm{C}$ and $\delta^{15} \mathrm{~N}$ analyses) of a variety of epifaunal species from a number of contrasting mangrove sites (Table 1): (1) a seaward exposed site and a more inland protected site with adjacent seagrass beds in Gazi Bay (Kenya), (2) 1 site in the Coringa Wildlife Sanctuary (CWS), a large estuarine mangrove system without nearby seagrass beds in the Godavari delta (Andhra Pradesh, India), and (3) 2 small mangrove sites along the coast of Sri Lanka: the basin forest of Galle and the lagoonal forest in Pambala. Whereas the sites in India and Kenya experience medium or high tidal amplitudes (spring tidal range of $\sim 2$ and $3.2 \mathrm{~m}$, respectively), the sites in Sri Lanka are both characterized by a low tidal amplitude (typically $\leq 0.20 \mathrm{~m}$ ). We supplemented these data sets with a compilation of relevant literature data in an attempt to look for general patterns in the origin of the carbon assimilated by different epifaunal groups across different mangrove ecosystems.

\section{MATERIALS AND METHODS}

Description of study areas. Gazi Bay, Kenya: Gazi Bay $\left(39^{\circ} 30^{\prime} \mathrm{E}, 4^{\circ} 22^{\prime} \mathrm{S}\right)$ is a shallow, tropical coastal water system, located $\sim 50 \mathrm{~km}$ south of Mombasa (Fig. 1a,b). The total area of the bay is approximately

Table 1. Overview of the main characteristics of the study sites. CWS: Coringa Wildlife Sanctuary, Andhra Pradesh

\begin{tabular}{|c|c|c|c|c|}
\hline Site & $\begin{array}{l}\text { Forest type } \\
\text { or setting }\end{array}$ & Dominant vegetation & $\begin{array}{l}\text { Tidal } \\
\text { range }(\mathrm{m})\end{array}$ & $\begin{array}{c}\text { Adjacent seagrass } \\
\text { beds? }\end{array}$ \\
\hline \multicolumn{5}{|l|}{ Gazi Bay (Kenya) } \\
\hline Upstream site & Estuarine & $\begin{array}{l}\text { Mixed: Rhizophora mucronata, } \\
\text { Avicennia marina, Ceriops tagal }\end{array}$ & $\sim 3.2$ & Yes \\
\hline Seaward site & Estuarine & Dominated by Sonneratia alba & $\sim 3.2$ & Yes \\
\hline CWS (India) & Estuarine & $\begin{aligned} \text { Mixed: } & \text { Avicennia officinalis, A. alba, } \\
& \text { Excoecaria agallocha }\end{aligned}$ & $\sim 2$ & No \\
\hline Galle (Sri Lanka) & Basin & Dominated by Rhizophora apiculata & $\leq 0.20$ & No \\
\hline Pambala (Sri Lanka) & Lagoonal (fringe) & Dominated by $R$. apiculata & $\leq 0.20$ & Yes \\
\hline
\end{tabular}




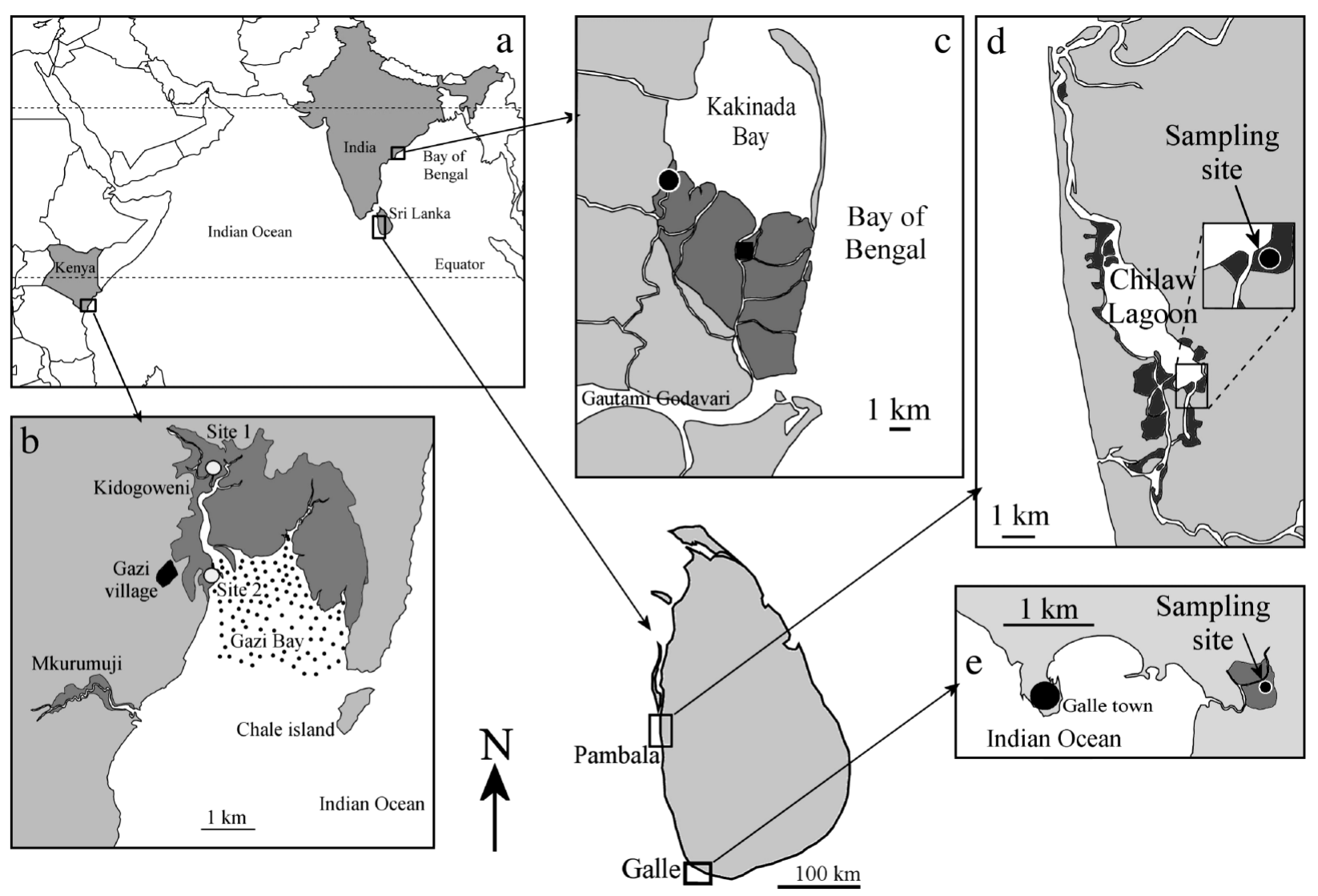

Fig. 1. Geographical location of the different sampling sites. (a) Overview, and location of (b) the 2 sampling sites in Gazi Bay, Kenya, (c) the sampling areas in the Coringa Wildlife Sanctuary, India, and $(d, e)$ the sampling sites in Galle and Pambala, Sri Lanka, respectively. Note that the black square in (c) indicates the areas where similar data were collected and presented in Bouillon et al. (2002). The darkest areas represent the main mangrove-covered regions and the dotted area in (b) shows the location of the main seagrass beds. See Table 1 for an overview of the main site characteristics

$10 \mathrm{~km}^{2}$, with an additional 6 to $7 \mathrm{~km}^{2}$ covered by mangroves, mostly Rhizophora mucronata, Sonneratia alba, Ceriops tagal, Bruguiera gymnorrhiza, Avicennia marina and Xylocarpus granatum. The bay itself harbors large areas ( $\sim 70 \%$ of the total area) of often dense seagrass beds, which are dominated by Thalassodendron ciliatum (Coppejans et al. 1992). The bay is open to the Indian Ocean through a relatively wide and shallow entrance in the south. Besides a few tidal creeks without freshwater inputs, the upper region of the bay receives freshwater from the Kidogoweni river, which cuts through the mangroves. Spring tidal range in Gazi Bay is reported to be $3.2 \mathrm{~m}$ (Kitheka 1997). Two intertidal sites were selected for the sampling of flora, sediments and invertebrates in July 2003: (Site 1) a mixed forest site located upstream along Kidogoweni creek, where vegetation consisted of $R$. mucronata, $A$. marina, C. tagal and a few X. granatum, and (Site 2) a seaward site predominantly vegetated by $S$. alba with some $R$. mucronata and A. marina, which bordered the edge of the bay and is, therefore, more likely to be influenced by seagrass inputs (Fig. 1).
Coringa Wildlife Sanctuary, Andhra Pradesh, India: The Coringa Wildlife Sanctuary (CWS, between $82^{\circ} 15^{\prime}$ and $82^{\circ} 22^{\prime} \mathrm{E}, 16^{\circ} 43^{\prime}$ and $17^{\circ} 00^{\prime} \mathrm{N}$, Fig. $1 \mathrm{a}, \mathrm{c}$ ) is part of the mangrove-covered area between Kakinada bay and the Gautami branch of the Godavari river (Fig. $1 \mathrm{a}, \mathrm{c})$. The CWS is dominated by mangrove forests (covering $\sim 150 \mathrm{~km}^{2}$ ) and tidal mudflats, the most abundant mangrove species being Avicennia marina, Avicennia officinalis, Excoecaria agallocha, Sonneratia apetala, Rhizophora mucronata and Rhizophora apiculata (Satyanarayana et al. 2002). Seagrass beds are absent from the areas adjacent to the mangroves. Tides are semidiurnal and spring tidal amplitude in the bay is $\sim 2 \mathrm{~m}$. Samples of vegetation, sediments and epifauna were collected in May and June 2001 in the northwestern part of the CWS, in an intertidal area dominated by A. officinalis, A. marina and E. agallocha along Matlapalem creek (Fig. 1a,c).

Galle, Sri Lanka: The mangroves in Galle, southwest Sri Lanka $\left(06^{\circ} 01^{\prime} \mathrm{N}\right.$ to $\left.80^{\circ} 14^{\prime} \mathrm{E}\right)$ cover an area of about $1.5 \mathrm{~km}^{2}$ and can be classified as a basin forest (sensu Lugo \& Snedaker 1974) (Fig. 1e). The forest is located 
approximately $600 \mathrm{~m}$ from the Indian Ocean shoreline and is traversed by 2 rivers, the Thalpe Ela and its tributary, the Galu Ganga. The forest at Galle is further characterized by a very irregular topography due to the burrowing activity of the mud lobster Thalassina anomala, and large patches of the forest are permanently inundated. This site experiences very low to no tidal influence and hence, limited exchange of organic material with adjacent environments, except during exceptionally high water levels in the river. The majority of samples for Galle were collected in an area predominantly vegetated by Rhizophora apiculata in March 2002 (dry season). Some initial samples were collected earlier in February-March 2000; and some stable isotope data on vegetation and sediments were available from a previous study (Bouillon et al. 2003).

Pambala, Sri Lanka: Pambala-Chilaw lagoon is situated in western Sri Lanka $\left(07^{\circ} 35^{\prime} \mathrm{N}, 79^{\circ} 47^{\prime} \mathrm{E}\right)$ and is similarly characterized as a low tidal amplitude system (tidal range not exceeding $0.2 \mathrm{~m}, \mathrm{~F}$. Dahdouh-Guebas pers. obs.), with $\sim 3.5 \mathrm{~km}^{2}$ of fringing mangroves (Fig. 1d). Surface water salinity in the lagoon varies strongly, between 0 and 55. All samples from Pambala were collected in a Rhizophora mucronata-dominated area in March 2002, but some previous data on vegetation and sediments were available (Bouillon et al. 2003).

In conclusion, the different sampling sites represent a variety of geomorphological settings (summarized in Table 1): (1) Pambala (Sri Lanka) as an example of a low tidal amplitude lagoon with fringing mangroves, (2) Galle (Sri Lanka) being a basin forest with insignificant tidal influence, (3) the CWS (India) as an example of a large estuarine mangrove forest with significant tidal influence but without seagrass inputs, and (4) 2 sites in the smaller estuarine system of Gazi Bay (Kenya), 1 of which is located in the interior part of the forest, the other site near the forest fringe and, therefore, more exposed to inputs from the extensive seagrass beds in the bay. The strongest tidal influence is experienced at Gazi Bay, Kenya.
Table 2. Overview of stable isotope data (average $\pm 1 \mathrm{SD}$ ) for flora, sediments and epifauna from Gazi Bay, Kenya (Sites 1 and 2, see Fig. 1b)

\begin{tabular}{|c|c|c|c|}
\hline & $\delta^{13} \mathrm{C}$ & $\delta^{15} \mathrm{~N}$ & $\mathrm{n}$ \\
\hline \multicolumn{4}{|l|}{ Site 1 (upstream site) } \\
\hline \multicolumn{4}{|l|}{ Flora } \\
\hline Avicennia marina & $-31.2 \pm 0.9$ & $3.0 \pm 0.8$ & 4 \\
\hline Ceriops tagal & $-29.4 \pm 0.9$ & $0.1 \pm 1.3$ & 4 \\
\hline Xylocarpus granatum & $-27.7 \pm 0.4$ & $-0.7 \pm 0.6$ & 4 \\
\hline Rhizophora mucronata & $-29.0 \pm 0.6$ & $0.0 \pm 0.7$ & 4 \\
\hline Microphytobenthos & $-22.1 /-22.1$ & $1.8 / 1.9$ & 2 \\
\hline Micro-epiflora & -24.2 & -2.4 & 1 (pooled) \\
\hline \multicolumn{4}{|l|}{ Sediments } \\
\hline Surface sediments & $-25.2 \pm 0.0$ & $2.1 \pm 1.2$ & 3 \\
\hline All sediment layers, up to $10 \mathrm{~cm}$ & $-25.2 \pm 0.2$ & $2.7 \pm 0.9$ & 15 \\
\hline \multicolumn{4}{|l|}{ Mollusks } \\
\hline Cerithidea decollata & $-21.6 \pm 0.8$ & $4.7 \pm 1.2$ & 7 \\
\hline Isognomon ephippium & $-22.8 \pm 1.0$ & $4.8 \pm 0.3$ & 5 \\
\hline Littoraria scabra & $-25.2 \pm 1.3$ & $1.7 \pm 0.3$ & 3 \\
\hline Trapezium cfr. sublaevigatum & $-23.0 \pm 0.2$ & $4.9 \pm 0.1$ & 3 \\
\hline Cassidula labrella & $-23.5 \pm 0.6$ & $5.6 \pm 0.1$ & 4 \\
\hline Onchidium spp. & $-23.7 \pm 1.5$ & $1.7 \pm 0.6$ & 5 \\
\hline Saccostrea cucculata & -23.7 & 4.8 & 1 \\
\hline Terebralia palustris & $-26.1 \pm 0.9$ & $3.5 \pm 1.1$ & 8 \\
\hline \multicolumn{4}{|l|}{ Brachyuran crabs } \\
\hline Epixanthus dentatus & $-22.6 /-20.8$ & $7.0 / 7.1$ & 2 \\
\hline Eurycarcinus natalensis & $-21.2 /-21.4$ & $6.6 / 7.2$ & 2 \\
\hline Metopograpsus thukuhar & $-21.0 /-21.0$ & $6.9 / 7.2$ & 2 \\
\hline Neosarmatium smithi & -30.3 & 5.5 & 1 \\
\hline Perisesarma guttatum & $-23.3 \pm 0.9$ & $4.2 \pm 0.7$ & 5 \\
\hline Perisesarma spp. & $-22.1 \pm 0.3$ & $4.0 \pm 0.3$ & 5 \\
\hline Uca chlorophthalmus & $-21.1 \pm 0.7$ & $3.2 \pm 0.8$ & 5 \\
\hline Uca urvillei & $-20.8 \pm 0.8$ & $4.1 \pm 0.7$ & 6 \\
\hline \multicolumn{4}{|l|}{ Site 2 (seaward site) } \\
\hline \multicolumn{4}{|l|}{ Flora } \\
\hline Avicennia marina & $-30.4 \pm 1.3$ & $3.3 \pm 0.4$ & 4 \\
\hline Sonneratia alba & $-27.0 \pm 0.8$ & $2.2 \pm 1.0$ & 4 \\
\hline Rhizophora mucronata & $-29.8 \pm 0.8$ & $-0.5 \pm 2.2$ & 4 \\
\hline \multicolumn{4}{|l|}{ Sediments } \\
\hline Surface sediments & $-23.0 \pm 0.9$ & $1.7 \pm 0.8$ & 3 \\
\hline All sediment layers, up to $10 \mathrm{~cm}$ & $-23.8 \pm 0.9$ & $2.1 \pm 0.4$ & 11 \\
\hline \multicolumn{4}{|l|}{ Mollusks } \\
\hline Neritina spp. & -17.9 & 4.2 & 1 \\
\hline Littoraria scabra & $-23.5 \pm 1.0$ & $1.1 \pm 1.4$ & 7 \\
\hline Crassostrea cucculata & $-18.4 \pm 0.6$ & $5.1 \pm 0.6$ & 5 \\
\hline Terebralia palustris & $-22.9 \pm 0.8$ & $4.5 \pm 0.5$ & 6 \\
\hline Clypeomorus spp. & $-19.0 \pm 0.7$ & $5.1 \pm 0.4$ & 5 \\
\hline \multicolumn{4}{|l|}{ Brachyuran crabs } \\
\hline Uca lactea annulipes & $-16.4 \pm 0.3$ & $2.2 \pm 1.1$ & 6 \\
\hline Uca urvillei & $-16.6 \pm 1.2$ & $3.0 \pm 1.0$ & 5 \\
\hline Perisesarma guttatum (adults) & $-20.1 \pm 0.5$ & $4.9 \pm 0.5$ & 5 \\
\hline Perisesarma guttatum (juveniles) & -19.1 & 5.2 & 1 \\
\hline Metopograpsus thukuhar & $-20.5 \pm 2.2$ & $5.5 \pm 0.2$ & 3 \\
\hline Thalamita crenata & -25.4 & 3.0 & 1 \\
\hline Sarmatium crassum & -23.6 & 4.4 & 1 \\
\hline Macrophthalmus depressus & $-16.4 \pm 0.2$ & $2.6 \pm 0.5$ & 5 \\
\hline \multicolumn{4}{|l|}{ Miscellaneous taxa } \\
\hline Tedania digitata & $-18.5 \pm 1.3$ & $4.9 \pm 1.8$ & 4 \\
\hline Barnacles (unidentified) & $-18.3 \pm 0.7$ & $7.2 \pm 0.4$ & 3 \\
\hline Clibanarius spp. & $-22.8 /-21.2$ & $4.9 / 2.8$ & 2 \\
\hline
\end{tabular}


Sampling and analytical techniques. At all sites, samples of epifauna and flora were taken from a $20 \mathrm{~m}$ by $20 \mathrm{~m}$ area in order to avoid spatial variations in producer stable isotope signatures (e.g. Fry et al. 2000). Although our sampling design does not, therefore, consider potential spatial and seasonal variations in the foodweb structure within sites, this should not limit our conclusions (see 'Discussion'). Sampling efforts were concentrated on those intertidal species (mainly mollusks and brachyuran crabs) that were numerically abundant in the area and, therefore, likely to play an important role in the overall processing of organic matter. Samples of vegetation and epifauna were collected by hand, while benthic microalgae were obtained by gently scraping them off the sediment where they formed a conspicuous layer; this was only the case in Gazi Bay, although previous data were available from the CWS. Mangrove leaf samples were picked from different trees to avoid any bias in the resulting isotope signatures. Typically, only surface sediments were collected, but for the 2 sites in Gazi, sediment cores were taken in the framework of another study and partitioned into $0-1,1-2,2-4$ and $4-10 \mathrm{~cm}$ layers. All faunal samples were kept in a cool box, transported to the field laboratory, washed and dried at $60^{\circ} \mathrm{C}$ for at least $48 \mathrm{~h}$. For some of the smaller crab species (e.g. Uca spp., smaller sesarmids) the gut and intestinal system were first removed and muscle tissue of the body was used; for larger crab species, muscle tissue was taken from the chelae. For mollusks, tissues were removed from their shell and analyzed whole. All samples were ground to a fine powder and sub-samples for $\delta^{13} \mathrm{C}$ subsequently acidified with dilute $(5 \%) \mathrm{HCl}$ before analysis to remove carbonates (except those of mangrove tissues). Sediment total organic carbon (TOC) and total nitrogen (TN) were determined by combusting pre-weighed samples in a ThermoFinnigan Flash1112 elemental analyzer. $\delta^{13} \mathrm{C}$ and $\delta^{15} \mathrm{~N}$ analysis of flora, fauna and sediments was performed with the aforementioned elemental analyzer, coupled to a ThermoFinnigan delta + XL via a Conflo III interface, with a typical reproducibility of $\pm 0.15 \%$ for both $\delta^{13} \mathrm{C}$ and $\delta^{15} \mathrm{~N}$. The samples from the CWS, however, were all measured on a dual inlet Finnigan Mat delta E off-line after cryogenic purification of the $\mathrm{CO}_{2}$ or $\mathrm{N}_{2}$, with a reproducibility of $0.2 \%$ for both $\delta^{13} \mathrm{C}$ and $\delta^{15} \mathrm{~N}$. All stable isotope ratios are expressed relative to the conventional standards (VPDB limestone and atmospheric $\mathrm{N}_{2}$ ) as $\delta$ values $(\%)$, defined as:

$$
\delta^{13} \mathrm{C}=\frac{X_{\text {sample }}-X_{\text {standard }}}{X_{\text {standard }}} \times 10^{3}
$$

where $X={ }^{13} \mathrm{C} /{ }^{12} \mathrm{C}$ or ${ }^{15} \mathrm{~N} /{ }^{14} \mathrm{~N}$ in the case of $\delta^{15} \mathrm{~N}$.

\section{RESULTS}

\section{Sedimentary organic matter}

Sediment at the upstream Gazi site had $\delta^{13} \mathrm{C}$ values $(-25.2 \pm 0.2 \%)$ somewhat more enriched than mangrove leaf tissues and showed relatively high TOC/TN ratios $(16.0 \pm 1.3$ atom, Fig. 2). At the seaward site, however, $\delta^{13} \mathrm{C}$ values of sediments were higher and more variable, particularly in the surface layers (the latter on average $-23.0 \pm 0.9 \%$ ). Sediments in Galle and Pambala showed consistently low $\delta^{13} \mathrm{C}$ values $(-27.8 \pm 1.1$ and $-27.5 \pm 0.9 \%$, respectively), high concentrations of organic carbon and high TOC/TN ratios (Fig. 2). Sediments in the CWS showed the highest $\delta^{13} \mathrm{C}$ values and had low TOC and TOC/TN ratios (Fig. 2).

\section{Primary producer stable isotope signatures}

Different mangrove species from the 2 sites in Gazi all showed typical $\delta^{13} \mathrm{C}$ signatures, with averages ranging between -27.0 and $-31.2 \%$ (Table 2, Fig. 3). The 3 mangrove species collected in the CWS had $\delta^{13} \mathrm{C}$ values similar to those found previously in the area (see Bouillon et al. 2002), but 2 species had markedly higher $\delta^{15} \mathrm{~N}$ values (Avicennia marina: $+8.9 \%$ and Excoecaria agallocha: $+8.8 \pm 0.3 \%$, Table 3, Fig. 3). Mangrove leaf tissues from Pambala all showed rather
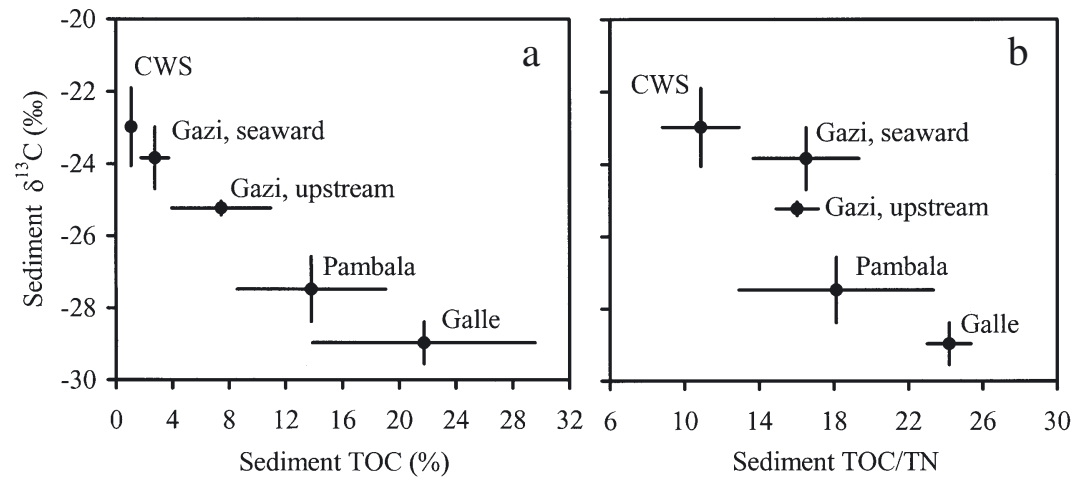

Fig. 2. Relationship between (a) sedimentary total organic carbon content (TOC) and $\delta^{13} \mathrm{C}$ of sediment organic carbon, and (b) sediment TOC/TN (total nitrogen) ratios (atom) and $\delta^{13} \mathrm{C}$ of sediment organic carbon, for the different systems/sites studied. Note that some additional data for Galle and Pambala, and all TOC and TOC/TN data for the CWS (Coringa Wildlife Sanctuary) were taken from Bouillon et al. (2003) 

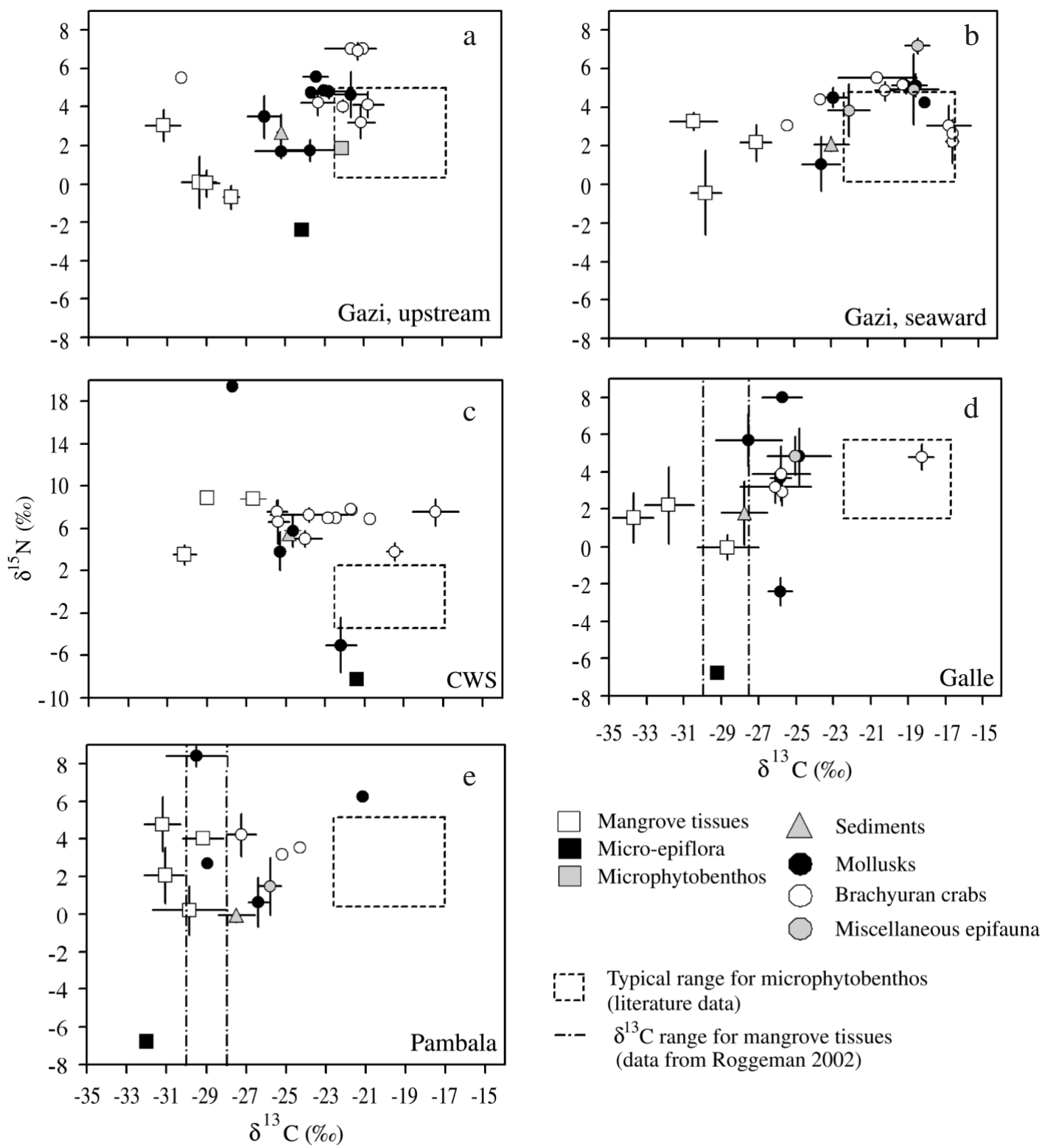

Typical range for microphytobenthos (literature data)

.$--\quad \delta^{13} \mathrm{C}$ range for mangrove tissues (data from Roggeman 2002)

Fig. 3. Plot of $\delta^{15} \mathrm{~N}$ versus $\delta^{13} \mathrm{C}$ for epifauna from the 5 study sites. (a) Upstream site along Kidogoweni creek (Gazi Bay, Kenya), (b) the seaward site (Gazi Bay, Kenya), (c) Coringa Wildlife Sanctuary, India, (d) Galle, Sri Lanka and (e) Pambala lagoon, Sri Lanka. Note the different scale of the $y$-axis in (c). See Table 1 for site characteristics

low $\delta^{13} \mathrm{C}$ values, with averages ranging between -29.2 and $-31.2 \%$ for various mangrove species (Table 4 , Fig. 3). The most depleted $\delta^{13} \mathrm{C}$ values for mangrove tissues, consistently lower than $-30 \%$, were found in Rhizophora apiculata and Bruguiera gmnorrhiza from Galle (Table 4, Fig. 3). E. agallocha, however, which mostly grows at slightly elevated patches in this area, had $\delta^{13} \mathrm{C}$ values in the usual range, averaging $-28.6 \%$. In contrast to mangrove tissues, micro-epiflora growing on mangrove stems (the composition of which was not studied) showed consistently low $\delta^{15} \mathrm{~N}$ values in all areas studied: $-8.2 \%$ in the CWS, $-6.8 \%$ in both Galle and Pambala, and $-2.4 \%$ in Gazi. $\delta^{13} \mathrm{C}$ values for these epiphytes were highly variable: $-21.4 \%$ in the CWS, $-24.2 \%$ in Gazi, $-29.2 \%$ in Galle and $-32.0 \%$ in Pambala (Tables 2 to 4 , Fig. 3). It should be noted that all data of micro-epiflora were gathered on pooled samples and we have no indications of the variability in isotope signatures of this source. Due to difficulties in sampling, we only have data for microphytobenthos from the upstream site in Gazi $\left(\delta^{13} \mathrm{C}:-22.0 \%\right.$, $\delta^{15} \mathrm{~N}$ : $+1.8 \%$ ), but previous data from the CWS were available $\left(\delta^{13} \mathrm{C}:-17.3 \pm 1.7 \%\right.$, $\delta^{15} \mathrm{~N}:+1.7 \pm 1.7 \%$, see Bouillon et al. 2002). 
Table 3. Overview of stable isotope data (average \pm 1 SD) for flora, sediments and epifauna from the Coringa Wildlife Sanctuary, Andhra Pradesh, India. Note that additional data from this area (but different localities within the CWS) can be found in Bouillon et al. (2002)

\begin{tabular}{|c|c|c|c|}
\hline & $\delta^{13} \mathrm{C}$ & $\delta^{15} \mathrm{~N}$ & $\mathrm{n}$ \\
\hline \multicolumn{4}{|l|}{ Flora } \\
\hline Avicennia marina & -29.0 & 8.9 & 1 (pooled) \\
\hline Avicennia officinalis & $-30.1 \pm 0.6$ & $3.5 \pm 0.9$ & 4 \\
\hline Excoecaria agallocha & $-26.6 \pm 0.6$ & $8.8 \pm 0.3$ & 5 \\
\hline Micro-epiflora & -21.4 & -8.2 & 1 (pooled) \\
\hline \multicolumn{4}{|l|}{ Sediments } \\
\hline Surface sediment & -24.9 & 5.6 & 1 (pooled) \\
\hline \multicolumn{4}{|l|}{ Mollusks } \\
\hline Pythia plicata & $-25.3 \pm 0.3$ & $3.8 \pm 1.8$ & 4 \\
\hline Onchidium spp. & $-22.2 \pm 0.8$ & $-5.0 \pm 2.6$ & 4 \\
\hline Teridinidae spp. & $-24.6 \pm 0.4$ & $5.8 \pm 1.5$ & 5 \\
\hline Polymesoda bengalensis & -27.7 & 19.5 & 1 \\
\hline \multicolumn{4}{|l|}{ Brachyuran crabs } \\
\hline Episesarma versicolor & $-25.4 \pm 0.5$ & $6.6 \pm 2.1$ & 4 \\
\hline Perisesarma bengalensis (adults) & $-25.4 \pm 0.5$ & $7.6 \pm 1.1$ & 6 \\
\hline Persisesarma bengalensis (juveniles) & $-24.0 \pm 0.8$ & $5.0 \pm 0.7$ & 6 \\
\hline Parasesarma asperum & $-23.8 \pm 2.0$ & $7.3 \pm 0.7$ & 4 \\
\hline Parasesarma plicatum & $-19.5 \pm 0.4$ & $3.8 \pm 0.8$ & 4 \\
\hline Metaplax distinctus & $-22.5 /-22.9$ & $7.0 / 7.0$ & 2 \\
\hline Uca rosea & -20.7 & 6.9 & 1 \\
\hline Uca triangularis & $-21.7 /-21.7$ & $7.8 / 7.8$ & 2 \\
\hline Uca urvillei & $-17.4 \pm 1.1$ & $7.6 \pm 1.3$ & 4 \\
\hline
\end{tabular}

highly variable both within and between different systems (overall range: -30.3 to $-18.9 \%$, with a fairly even distribution between these extremes). In the CWS, for example (Table 3, Fig. 3), average $\delta^{13} \mathrm{C}$ values for sesarmids were $-25.4 \%$ o (adult Perisesarma bengalensis and Episesarma versicolor), -24.0 (juvenile $P$. bengalensis), -23.8\% (Parasesarma asperum), and $-19.5 \%$ (juvenile $P a$ rasesarma plicatum). As previously noted for this area (Bouillon et al. 2002), ocypodid crabs (3 Uca spp.) and Metaplax distinctus were found at the more enriched end of the $\delta^{13} \mathrm{C}$ range, and mollusks showed a diverse $\delta^{13} \mathrm{C}$ and $\delta^{15} \mathrm{~N}$ pattern (Table 3, Fig. 3). With the exception of Uca lactea annulipes, invertebrates from Galle all showed relatively uniform $\delta^{13} \mathrm{C}$ values (Table 4, Fig. 3), with averages between -27.5 and $-24.8 \%$. However, $\delta^{15} \mathrm{~N}$ values ranged more widely, with unusually low values for Pythia plicata $(-2.4 \pm 0.7 \%$ ) and high values for the 2 bivalves examined (i.e. Polymesoda spp. and an uniden-

\section{Consumer stable isotope signatures}

Invertebrates from both sites in Gazi showed quite diverse stable isotope signatures, ranging overall between -30.3 and $-16.4 \%$ of for $\delta^{13} \mathrm{C}$, and between 1.1 and $7.2 \%$ for $\delta^{15} \mathrm{~N}$ (Table 2, Fig. 3). However, $\delta^{13} \mathrm{C}$ values were typically higher at the seaward site (Fig. 3). Our $\delta^{13} \mathrm{C}$ data on mangrove sesarmids are tified oyster, $5.7 \pm 1.4$ and $8.0 \pm 0.2 \%$, Table 4, Fig. 3). Invertebrates from Pambala, with the exception of Cerithidea cingulata, similarly showed a fairly narrow range of $\delta^{13} \mathrm{C}$ signatures, with averages between -28.5 and $-24.3 \%$ (Table 4, Fig. 3). As in Galle, the filter-feeding Polymesoda spp. showed distinctly higher $\delta^{15} \mathrm{~N}$ values $(8.4 \pm 0.5 \%$ o) compared to other invertebrates (0.6 to $6.2 \%$ ).
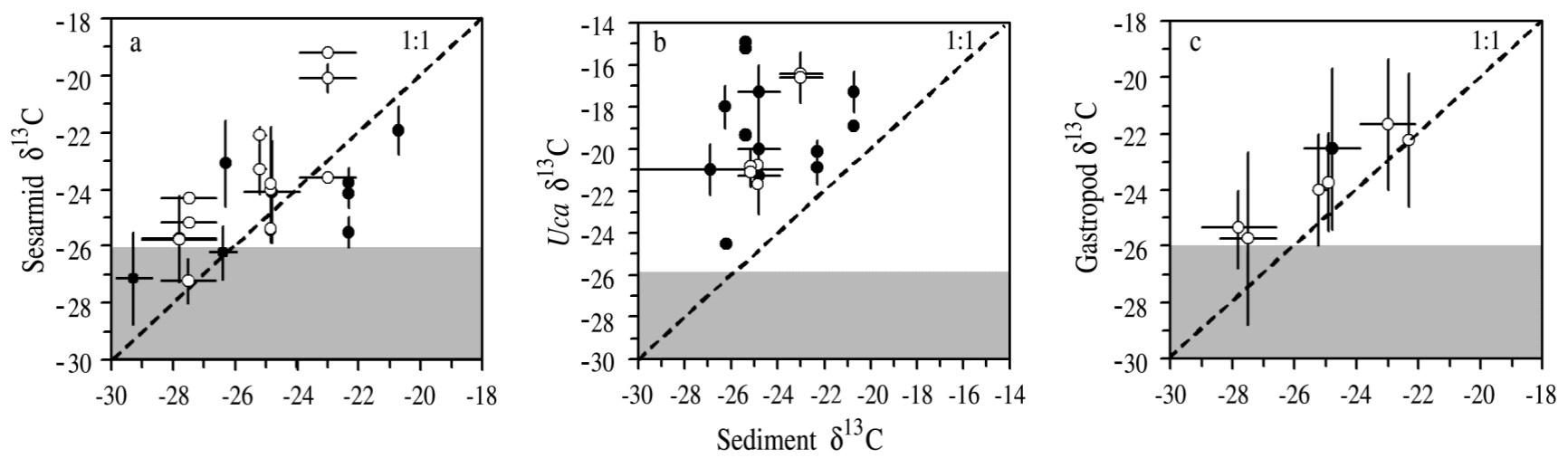

Fig. 4. Relationship between surface sediment $\delta^{13} \mathrm{C}$ values and those recorded in various species of (a) Sesarminae, (b) Uca spp. and (c) gastropods (data from all species at a specific site were pooled for c). Data were compiled from the 5 sites mentioned in this study and additional literature data (data sources available on request). •: literature data; O: data from this study. Grey shaded areas show typical range of values for mangrove-derived organic matter. Literature data taken from Fry (1984), Rodelli et al. (1984), France (1998), Thimdee et al. (2001), Bouillon et al. (2002) and Hsieh et al. (2002) 
Table 4. Overview of stable isotope data (average $\pm 1 \mathrm{SD}$ ) for flora, sediments, particulate organic carbon (POC) and epifauna from Pambala and Galle, Sri Lanka

\begin{tabular}{|c|c|c|c|}
\hline & $\delta^{13} \mathrm{C}$ & $\delta^{15} \mathrm{~N}$ & $\mathrm{n}$ \\
\hline \multicolumn{4}{|l|}{ Pambala, Sri Lanka } \\
\hline \multicolumn{4}{|l|}{ Flora } \\
\hline Avicennia officinalis & $-29.9 \pm 1.8$ & $0.2 \pm 1.3$ & 5 \\
\hline Bruguiera gymnorrhiza & $-31.1 \pm 1.0$ & $2.1 \pm 1.5$ & 4 \\
\hline Rhizophora apiculata & $-29.2 \pm 1.0$ & $4.0 \pm 0.7$ & 5 \\
\hline Rhizophora mucronata & $-31.2 \pm 0.9$ & $4.8 \pm 1.5$ & 15 \\
\hline Micro-epiflora & -32.0 & -6.8 & 1 (pooled) \\
\hline \multicolumn{4}{|l|}{ Sediments } \\
\hline Surface sediments & $-27.5 \pm 0.9$ & $-0.1 \pm 0.3$ & $18\left(4\right.$ for $\left.\delta^{15} \mathrm{~N}\right)$ \\
\hline \multicolumn{4}{|l|}{ Mollusks } \\
\hline Pythia plicata & $-26.4 \pm 0.5$ & $0.6 \pm 1.3$ & 4 \\
\hline Cassidula mustelina & $-28.0 /-29.0$ & $2.7 / 2.7$ & 2 \\
\hline Cerithidea cingulata & $-21.3 /-21.0$ & $6.2 / 6.3$ & 2 \\
\hline Polymesoda spp. & $-29.5 \pm 1.5$ & $8.4 \pm 0.5$ & 3 \\
\hline \multicolumn{4}{|l|}{ Brachyuran crabs } \\
\hline Episesarma tetragonum & -25.2 & 3.2 & 1 \\
\hline Perisesarma dussumieri & $-27.3 \pm 0.8$ & $4.2 \pm 1.2$ & 6 \\
\hline Pseudosesarma crassimanum & -24.3 & 3.5 & 1 \\
\hline \multicolumn{4}{|l|}{ Miscellaneous } \\
\hline Isopoda (unidentified) & $-25.8 \pm 0.6$ & $1.5 \pm 1.6$ & 4 \\
\hline \multicolumn{4}{|l|}{ Galle, Sri Lanka } \\
\hline \multicolumn{4}{|l|}{ Flora } \\
\hline Rhizophora apiculata & $-31.8 \pm 1.3$ & $2.2 \pm 5.0$ & $13\left(7\right.$ for $\left.\delta^{15} \mathrm{~N}\right)$ \\
\hline Excoecaria agallocha & $-28.6 \pm 1.6$ & $0.0 \pm 0.7$ & $8\left(6\right.$ for $\left.\delta^{15} \mathrm{~N}\right)$ \\
\hline Bruguiera gymnorrhiza & $-33.7 \pm 1.1$ & $1.5 \pm 1.3$ & $9\left(7\right.$ for $\left.\delta^{15} N\right)$ \\
\hline Micro-epiflora & -29.2 & -6.8 & 1 (pooled) \\
\hline \multicolumn{4}{|l|}{ Sediments and POC } \\
\hline Surface sediments & $-27.8 \pm 1.2$ & $1.8 \pm 1.7$ & $17\left(15\right.$ for $\left.\delta^{15} \mathrm{~N}\right)$ \\
\hline $\mathrm{POC}$ & $-26.9 \pm 1.3$ & $6.8 \pm 2.6$ & 6 \\
\hline \multicolumn{4}{|l|}{ Mollusks } \\
\hline Terebralia palustris & $-24.8 \pm 1.7$ & $4.8 \pm 1.5$ & 10 \\
\hline Cassidula mustelina & $-25.8 \pm 0.6$ & $3.7 \pm 0.6$ & 6 \\
\hline Pythia plicata & $-25.8 \pm 0.6$ & $-2.4 \pm 0.7$ & 6 \\
\hline Polymesoda spp. & $-27.5 \pm 1.8$ & $5.7 \pm 1.4$ & 6 \\
\hline $\begin{array}{l}\text { Unidentified oyster } \\
\text { Brachyuran crabs }\end{array}$ & $-25.7 \pm 1.1$ & $8.0 \pm 0.2$ & 5 \\
\hline Perisesarma dussumieri & $-25.8 \pm 1.5$ & $3.9 \pm 1.5$ & 6 \\
\hline Perisesarma bengalensis & $-25.7 \pm 0.1$ & $2.9 \pm 0.7$ & 3 \\
\hline Uca lactea annulipes & $-18.3 \pm 0.7$ & $4.8 \pm 0.7$ & 5 \\
\hline \multicolumn{4}{|l|}{ Miscellaneous } \\
\hline Clibanarius spp. & $-25.0 \pm 1.5$ & $4.9 \pm 1.0$ & 5 \\
\hline
\end{tabular}

reflect the balance between local inputs from mangroves (high TOC, high TOC/TN and low $\delta^{13} \mathrm{C}$ ) and inputs from the water column (low TOC, low TOC/TN and higher but variable $\left.\delta^{13} \mathrm{C}\right)$. Thus, our data show that both the fringing lagoonal mangroves in Pambala and the basin forest of Galle are 'retention' sites, where mangrove carbon accumulates and dominates the sedimentary organic matter pool. For the CWS and Gazi, however, a balance exists between local mangrove inputs and tidally imported organic matter (see also Hemminga et al. 1994, Slim et al. 1996). Moreover, the data from the seaward site in Gazi show that seagrass inputs (with $\delta^{13} \mathrm{C}$ values in the area between -19.7 and $-10.7 \%$, Hemminga et al. 1994, authors' unpubl. data) are more important at this location than at the upstream sampling site .

\section{Consumption of different primary food sources by mangrove epifauna}

Before discussing the differences in $\mathrm{C}$ and $\mathrm{N}$ sources for epifaunal communities between different sites, we will first briefly examine the major primary organic matter sources for the 2 dominant groups of epifauna, i.e. brachyuran crabs and mollusks, at the different sites studied.

\section{Brachyuran crabs}

Brachyuran crabs and mollusks are typically the dominant groups of mangrove epifauna and can attain very high densities (e.g. Ashton \& Macin-

\section{DISCUSSION}

\section{Differences in sedimentary organic matter origin}

The different sites in this study represent different geomorphological settings (i.e. estuarine, lagoonal and basin forests, sensu Lugo \& Snedaker 1974) with varying tidal amplitude and, therefore, the relative importance of local vascular plant material and aquatic organic matter sources to the sedimentary pool varies significantly (Fig. 2). It has previously been shown (Bouillon et al. 2003) that for the majority of systems, these parameters tosh 2002). Their role in nutrient cycling (Lee 1998) and in sediment biogeochemistry, via bioturbation, is therefore considered to be large. Even though the focus of most studies has been on the effect of sesarmid crabs on leaf litter dynamics (e.g. Ashton 2002), several studies have stressed that different groups of mangrove crabs display a wide range of feeding preferences. Although for several of the larger species $\delta^{13} \mathrm{C}$ values were on average within $\sim 4 \%$ of those of mangrove tissues (which indicates substantial inputs from mangrove litter, albeit with some contributions of other dietary sources), several species showed consistently 
high $\delta^{13} \mathrm{C}$ values tending towards those typical of microphytobenthos (e.g. Perisesarma spp. from Gazi: $-20.1 \pm 0.5$ and $-22.1 \pm 0.3 \%$, Parasesarma plicatum from the CWS: $-19.5 \pm 0.4 \%$ o). Thus, although some mangrove sesarmids undoubtedly rely substantially on mangrove carbon, this is clearly very species-specific. Secondly, when comparing sesarmid $\delta^{13} \mathrm{C}$ data from all the sites studied here and with the inclusion of literature data, we find (despite the species-specific variation) a good overall correlation between the isotope signature in sedimentary organic carbon and that in sesarmids (Fig. 4a, Spearman rank correlation test: $\mathrm{p}=$ $0.0057, \mathrm{R}^{2}=0.37$ ). The latter confirms the idea that many sesarmids may spend more time feeding on the sediment surface than actively searching for fallen leaves (Skov \& Hartnoll 2002) and indicates that the C and $\mathrm{N}$ source for this group of epifauna will partially depend on the geomorphological settings of the system, as the latter is a primary determinant of the origin of sedimentary organic matter (Bouillon et al. 2003). Such a correlation with sediment $\delta^{13} \mathrm{C}$ values is not significant (Spearman rank correlation test: $\mathrm{p}=0.349, \mathrm{R}^{2}=$ 0.06 ) for the second major group of brachyurans found in mangroves, ocypodid crabs (mostly Uca spp. and Macrophthalmus spp., see Tables 2 to 4). Ocypodid crabs are typical deposit feeders which forage on the sediment surface. Stable isotope data presented earlier (e.g. Rodelli et al. 1984, Marguillier et al. 1997, France 1998, Hsieh et al. 2002) and in this study consistently show high $\delta^{13} \mathrm{C}$ values, ranging between -24.5 and $-12.5 \%$, with an average of $-18.9 \pm 2.3 \%$, and with a distribution markedly different from that of sesarmids. These data indicate a clear selectivity for ${ }^{13} \mathrm{C}$-enriched carbon sources such as microphytobenthos. Among the other brachyuran crab taxa associated with mangroves, Eurycarcinus natalensis, Epixanthus dentatus and Metopograpsus thukuhar from Gazi Bay clustered close together and their stable isotope signatures (high $\delta^{13} \mathrm{C}$ and $\delta^{15} \mathrm{~N}$, Table 2) are suggestive of little direct inputs from mangroves and of significant predation on lower trophic levels, consistent with literature data (e.g. Dahdouh-Guebas et al. 1999).

\section{Mollusks}

Most of the scarce, previously published stable isotope data for bivalves from intertidal mangrove habitats (Rodelli et al. 1984) point towards microalgal food sources, but the data presented here show a more diverse pattern. Both the Polymesoda spp. (sampled in the CWS, Galle and Pambala) and the unidentified oyster from Galle show consistently low $\delta^{13} \mathrm{C}$ signatures, close to those of mangrove tissues. However, this resemblance does not necessarily indicate a strong reliance on mangrove carbon, as aquatic microalgal production may be similarly depleted in ${ }^{13} \mathrm{C}$ due to low $\delta^{13} \mathrm{C}$ values in the dissolved inorganic carbon (DIC) pool (e.g. surface water $\delta^{13} \mathrm{C}_{\text {DIC }}$ values in Galle ranged between -14.2 and $-7.8 \%$, authors' unpubl. data, whereas typical seawater values are close to $0 \%$ ). The data in Table 4 (see also Fig. 3) also show that these bivalves were consistently enriched in ${ }^{15} \mathrm{~N}$ compared to most other consumers in the ecosystem, despite similar $\delta^{13} \mathrm{C}$ values. For Galle, the only site with significant permanently inundated sites, suspended organic matter was similarly enriched in ${ }^{15} \mathrm{~N}$ compared to sediment organic matter. Thus, the situation for these bivalve species remains somewhat unclear, with strong contributions from either mangrove-derived material (after microbial processing in the water column, which can result in higher $\delta^{15} \mathrm{~N}$ values, e.g. see De Brabandere et al. 2002) or from aquatic primary production. A special group of bivalves are wood-boring species such as the Teredinidae (which were sampled in the CWS), known to harbor symbiotic cellulolytic bacteria capable of $\mathrm{N}_{2}$-fixation. Our $\delta^{13} \mathrm{C}$ data of Teredinidae $(-24.6 \pm$ $0.4 \%$ ) are consistent with Avicennia wood $\left(\delta^{13} \mathrm{C}\right.$ : $-25.7 \%$ ) being the major $\mathrm{C}$ source, but the $\delta^{15} \mathrm{~N}$ signatures of the Teredinidae $(+5.8 \pm 0.5)$ are only slightly higher than those of the $\log \left(\delta^{15} \mathrm{~N}:+5.1 \%\right)$ in which they were collected, indeed suggesting an additional input of $\mathrm{N}_{2}$-fixation to the $\mathrm{N}$-requirements of these bivalves. Another bivalve from dead mangrove wood in Gazi, Trapezium cfr. sublaevigatum (which does not have such a symbiotic relationship), showed $\delta^{13} \mathrm{C}$ and $\delta^{15} \mathrm{~N}$ values markedly more distant from those of mangroves (Table 2, Fig. 3), suggesting additional inputs from aquatic $\mathrm{C}$ and $\mathrm{N}$ sources.

Two previous studies have found unexpectedly low $\delta^{15} \mathrm{~N}$ values in some mangrove mollusks (Christensen et al. 2001, Bouillon et al. 2002) and similar data were obtained here, i.e. for Pythia plicata from Galle, Onchidium spp. from the CWS and to a lesser extent from Gazi, and for Littoraria scabra from Gazi (see Tables 2 to 4, Fig. 3), all of which are species typically found grazing on mangrove roots or stems. The unusually low $\delta^{15} \mathrm{~N}$ values found here in micro-epiflora $\left(\delta^{15} \mathrm{~N}\right.$ $=-6.8 \%$ in both Pambala and Galle, $\delta^{15} \mathrm{~N}=-8.2 \%$ in the CWS, $-2.4 \%$ in Gazi Bay) offer a convincing explanation for these consumer $\delta^{15} \mathrm{~N}$ values and indicate a significant input of $\mathrm{N}$ from such a source. The $\delta^{15} \mathrm{~N}$ values of the epiflora are likely to reflect the importance of atmospheric nitrogen (from precipitation and/or through $\mathrm{N}_{2}$-fixation) as their $\mathrm{N}$ source (see e.g. Hietz et al. 1999 for vascular epiphytes). It is worth noting that some other gastropods often found in large numbers on mangrove stems, such as Cerithidea obtusa (found in the CWS, see Table 3) or C. decollata (found in Gazi, see Table 2) do not show evidence of extensive feeding 
on ${ }^{15} \mathrm{~N}$-depleted epiflora, but as these species are also found on the sediment surface, the isotope data suggest that these are more likely to feed on sediment organic matter and microphytobenthos. In conclusion, the $\delta^{13} \mathrm{C}$ and $\delta^{15} \mathrm{~N}$ patterns (Fig. 3) indicate a diverse range of feeding preferences for mangrove-inhabiting mollusks.

\section{Differences in $\mathbf{C}$ and $\mathrm{N}$ utilization between contrasting mangrove systems}

In a previous study, we found no evidence for a dominant role of mangroves in sustaining epifaunal invertebrate communities (Bouillon et al. 2002). However, as these data came from an estuarine system where tidally imported organic matter was found to dominate the sediment pool, we hypothesized that such a situation may not be representative for other types of mangrove systems, in particular for those where exchange of material with the aquatic environment is limited due to low tidal action.

The data gathered in this study provide a first test of this hypothesis. First, as noted above, we found that the origin of sedimentary organic matter at least partially determines the overall dependency of sesarmid crabs on different primary sources (Fig. 4a), despite the obvious fact that different species have different feeding specializations. In Fig. 4c, data for all gastropod species are presented per site with data from this study, as well as those given in Rodelli et al. (1984) and Bouillon et al. (2002). Again, despite their varying feeding specializations (some being selective for epiflora, microphytobenthos or mangrove litter, see 'Mollusks' above), an analogous pattern as that found for sesarmids shows up for gastropods, i.e. a markedly lower direct use of mangrove carbon in estuarine forest types where inputs from the aquatic environment are significant (Spearman rank correlation test for the relationship between sediment and gastropod $\delta^{13} \mathrm{C}: \mathrm{p}=$ $0.029, \mathrm{R}^{2}=0.86$ ). It is worth mentioning that the slope of the relationship between $\delta^{13} \mathrm{C}$ of consumers and sediments is markedly different for sesarmids (slope of $~ 0.56$ ) and gastropods (slope of $\sim 1.0$ ).

The same conclusions are also evident when comparing the panels in Fig. 3: much of the species data for the low-amplitude sites in Sri Lanka cluster quite closely together in the range expected for species that assimilate significant mangrove-derived organic matter (from the sediment pool); for the upstream site in Gazi and for the CWS the data are more scattered; and at the seaward site in Gazi, a clear trend towards much more enriched values is evident. However, for both Pambala and Galle, our $\delta^{13} \mathrm{C}$ values for most mangrove tree species are rather low. Roggeman (2002) analyzed Rhizophora mucronata leaves from both areas during the same sampling period and found typically higher $\delta^{13} \mathrm{C}$ values, ranging between -29 and $-25 \%$. A clear relationship with tree age (as measured by the circumference of the tree crown or the height of the tree) was found, with younger trees showing more negative $\delta^{13} \mathrm{C}$ values (between -32 and $-30 \%$ ). A generally more enriched $\delta^{13} \mathrm{C}$ signature for mangrove leaf tissues at both Galle and Pambala would be consistent with indications from sedimentary TOC and TOC/TN data that the organic matter pool is derived primarily from mangrove tissues, and the sediment $\delta^{13} \mathrm{C}$ signatures $(-27.5 \pm 0.9 \%$ in Pambala, $-27.8 \pm 1.2 \%$ in Galle) are indeed closer to the data from Roggeman (2002). In this interpretation, the trophic dependency of epifauna on mangroves in both Galle and Pambala would overall be large, and likely to occur both directly through feeding on mangrove leaves and indirectly through feeding on sediment organic matter (which is strongly enriched in $\mathrm{N}$ compared to senescent mangrove leaves, e.g. see Skov \& Hartnoll 2002). Finally, it should be mentioned that our sampling design did not accommodate potential seasonal and/or spatial variations in the foodweb structure within sites. However, even if such variations were present, we do not see any arguments to conclude that these would interfere with the general patterns observed in Figs. $3 \& 4$.

\section{Results of litter removal experiments and stable isotope analyses: how compatible are they?}

The idea that much of the mangrove litter produced is removed and/or consumed by mangrove epifauna (at least in the Indo-Pacific, McIvor \& Smith 1995 and even there not in all forest zones alike or depending on the tidal stage, see Slim et al. 1997 and Ólafsson et al. 2002) seems to contrast with the stable isotope results presented and compiled in this study. They demonstrate that, from a community perspective, only a limited number of species rely substantially and directly on mangrove carbon, and that, when available, a range of other sources are used by the invertebrate community. There are several points which can be raised to reconcile these 2 superficially contrasting viewpoints. First, the fact that a large proportion of the leaf litter is removed and/or consumed by the local crab fauna does not necessarily imply that mangrove leaves are the dominant item in their diet, as the population of sesarmids may consume even more of 'something else'. In this respect, the study of Skov \& Hartnoll (2002) is particularly enlightening, as their field observations clearly demonstrate that sesarmids spend considerably more time feeding off the sediment surface than collecting or eating leaves. Even though this does not necessarily imply that more sediment organic mat- 
ter is assimilated than mangrove leaves, it does indicate the importance of deposit feeding. Evidently, the sources of organic matter present in the sediment and the degree of selectivity with which sesarmids feed on it (both of which may be highly variable) will further determine which carbon sources contribute to their diet and in which proportions. Secondly, much of the work on the trophic significance of different sources in mangrove ecosystems has focussed on a limited number of invertebrate groups or species, notably sesarmids and a disproportionate number of studies on Terebralia palustris (e.g. Slim et al. 1997). From a community perspective, however, this may severely bias our view of the importance of mangrove litter, as the often diverse invertebrate community apparently displays a wide variety of feeding specializations.

Lastly, it should also be noted that in view of the significant differences in elemental ratios between different food sources available to intertidal consumers (e.g. mangrove leaves have a very low $\mathrm{N}$ content, microphytobenthos is much richer in $\mathrm{N}$, etc.), the contributions of $\mathrm{C}$ and $\mathrm{N}$ from any dietary source are not necessarily equal, but likely to be proportional to the $\mathrm{C} / \mathrm{N}$ ratios of the substrates. The latter implies that the dependency in invertebrate communities on mangrove-derived $\mathrm{N}$ will generally be less than their dependency on mangrove-derived $\mathrm{C}$.

\section{CONCLUSIONS}

Our data strongly suggest that where multiple $\mathrm{C}$ and $\mathrm{N}$ sources are available, intertidal mangrove epifaunal communities exploit all available food resources with clear and consistent differences in utilization patterns between different taxa or species. Secondly, we have shown a strong influence of the relative inputs of local and tidally imported carbon sources (as reflected in sedimentary $\delta^{13} \mathrm{C}$ values) on the relative importance of mangrove carbon to several groups of epifauna. This variability shows strong similarities to the variable contribution of different carbon sources to sedimentary microbial communities observed across various mangrove sites (Bouillon et al. 2004).

Although $\delta^{15} \mathrm{~N}$ was a poor source indicator except for micro-epiflora, which showed consistently low $\delta^{15} \mathrm{~N}$ values in all sites ( -2.4 to $-8.2 \%$ ), we can expect that the importance of mangroves as a $\mathrm{N}$ source for invertebrates is less than for $\mathrm{C}$, due to the low $\mathrm{N}$ content of mangrovederived organic matter. Finally, it is worth pointing out that the areal extent of 'closed' mangrove systems (i.e. in which mangroves appear to provide most of the carbon fuelling epifaunal and microbial communities) is rather limited on a global scale, as the largest mangrovecovered areas are found in estuarine and deltaic systems.
Acknowledgements. Funding for this work was provided by the Fonds voor Wetenschappelijk Onderzoek (FWO-Vlaanderen, contract G.0118.02) and by EC-INCO project contract ERB IC18-CT98-0295. S.B. and T.M. are both postdoctoral fellows with the FWO-Vlaanderen. We are grateful to K. Ratnam for help during fieldwork in India, to I. De Mesel, A. V. Borges and the staff of the Kenya Marine and Fisheries Research Institute (Mombasa) for fieldwork assistance in Kenya, to V. de Schuyter, M. Roggeman and A. Verheyden for help during sample collection in Sri Lanka, to P. Davie (Queensland Museum, Australia) and D. P. Gillikin for their expertise in identifying most of the crabs, and to A. Callea for his help in identifying some of the mollusks from Kenya. The excellent help of J. Bosire and J. Kairo in organizing logistics in Kenya was much appreciated. D. Gillikin and 3 anonymous referees provided very insightful and constructive comments to an earlier version of this manuscript.

\section{LITERATURE CITED}

Ashton EC (2002) Mangrove sesarmid crab feeding experiments in peninsular Malaysia. J Exp Mar Biol Ecol 273:97-119

Ashton EC,Macintosh DJ (2002) Preliminary assessment of the plant diversity and community ecology of the Sematan mangrove forest, Sarawak, Malaysia. Forest Ecol Manag 166:111-129

Bouillon S, Koedam N, Raman AV, Dehairs F (2002) Primary producers sustaining macro-invertebrate communities in intertidal mangrove forests. Oecologia 130:441-448

Bouillon S, Dahdouh-Guebas F, Rao AVVS, Koedam N, Dehairs F (2003) Sources of organic carbon in mangrove sediments: variability and some possible implications for ecosystem functioning. Hydrobiologia 495:33-39

Bouillon S, Moens T, Koedam N, Dahdouh-Guebas F, Baeyens W, Dehairs F (2004) Variability in the origin of carbon substrates for bacterial communities in mangrove sediments. FEMS Microbiol Ecol 49:171-179

Christensen JT, Sauriau PG, Richard P, Jensen PD (2001) Diet in mangrove snails: preliminary data on gut contents and stable isotope analysis. J Shellfish Res 20:423-426

Coppejans E, Beeckman H, De Wit M (1992) The seagrass and associated macroalgal vegetation of Gazi Bay (Kenya). Hydrobiologia 247:59-75

Dahdouh-Guebas F, Giuggioli M, Oluoch A, Vannini M, Cannicci S (1999) Feeding habits of non-ocypodid crabs from two mangrove forests in Kenya. Bull Mar Sci 64:291-297

De Brabandere L, Dehairs F, Van Damme S, Brion N, Meire P, Daro $N$ (2002) $\delta^{15} \mathrm{~N}$ and $\delta^{13} \mathrm{C}$ dynamics of suspended organic matter in freshwater and brackish waters of the Scheldt estuary. J Sea Res 48:1-15

Ewel KC, Twilley RR, Ong JE (1998) Different kinds of mangrove forests provide different goods and services. Glob Ecol Biogeogr Lett 7:83-94

France R (1998) Estimation of the assimilation of mangrove detritus by fiddler crabs in Laguna Joyuda, Puerto Rico, using dual stable isotopes. J Trop Ecol 14:413-425

Fratini S, Cannicci S, Vannini M (2000) Competition and interaction between Neosarmatium smithi (Crustacea: Grapsidae) and Terebralia palustris (Molluska: Gastropoda) in a Kenyan mangrove. Mar Biol 137:309-316

Fry B (1984) ${ }^{13} \mathrm{C} /{ }^{12} \mathrm{C}$ ratios and the trophic importance of algae in Florida Syringodium filiforme seagrass meadows. Mar Biol 79:11-19

Fry B, Bern AL, Ross MS, Meeder JF (2000) $\delta^{15} \mathrm{~N}$ studies of nitrogen use by the red mangrove, Rhizophora mangle L. in south Florida. Estuar Coast Shelf Sci 50:291-296 
Hemminga MA, Slim FJ, Kazungu J, Ganssen GM, Nieuwenhuize J, Kruyt NM (1994) Carbon outwelling from a mangrove forest with adjacent seagrass beds and coral reefs (Gazi Bay, Kenya). Mar Ecol Prog Ser 106:291-301

Hietz P, Wanek W, Popp M (1999) Stable isotopic composition of carbon and nitrogen and nitrogen content in vascular epiphytes along an altitudinal transect. Plant Cell Environ 22:1435-1443

Hsieh HL, Chen CP, Chen YG, Yang HH (2002) Diversity of benthic organic matter flows through polychaetes and crabs in a mangrove estuary: $\delta^{13} \mathrm{C}$ and $\delta^{34} \mathrm{~S}$ signals. Mar Ecol Prog Ser 227:145-155

Kitheka JU (1997) Coastal tidally-driven circulation and the role of water exchange in the linkage between tropical coastal ecosystems. Estuar Coast Shelf Sci 45:177-187

Lee SY (1998) Ecological role of grapsid crabs in mangrove ecosystems: a review. Mar Freshw Res 49:335-343

Lugo AE, Snedaker SC (1974) The ecology of mangroves. Annu Rev Ecol Syst 5:39-64

Marguillier S, van der Velde G, Dehairs F, Hemminga MA, Rajagopal S (1997) Trophic relationships in an interlinked mangrove-seagrass ecosystem as traced by $\delta^{13} \mathrm{C}$ and $\delta^{15} \mathrm{~N}$. Mar Ecol Prog Ser 151:115-121

McIvor CC, Smith TJ III (1995) Differences in the crab fauna of mangrove areas at a Southwest Florida and a Northeast Australia location: implications for leaf litter processing. Estuaries 18:591-597

Ólafsson E, Buchmayer S, Skov MW (2002) The east African decapod crab Neosarmatium meinerti (de Man) sweeps mangrove floors clean of leaf litter. Ambio 31:569-573

Editorial responsibility: Otto Kinne (Editor),

Oldendorf/Luhe, Germany
Rodelli MR, Gearing JN, Gearing PJ, Marshall N, Sasekumar A (1984) Stable isotope ratios as a tracer of mangrove carbon in Malaysian ecosystems. Oecologia 61:326-333

Roggeman M (2002) Stable carbon isotope composition of mangrove wood in relation to environmental factors in a historical perspective (in Dutch). MSc thesis, Vrije Universiteit Brussel, Brussels

Satyanarayana B, Raman AV, Dehairs F, Kalavati C, Chandramohan P (2002) Mangrove floristic and zonation patterns of Coringa, Kakinada bay, East coast of India. Wetlands Ecol Manag 10:25-39

Skov MW, Hartnoll RG (2002) Paradoxical selective feeding on a low-nutrient diet: Why do mangrove crabs eat leaves? Oecologia 131:1-7

Slim FJ, Hemminga MA, Cocheret de la Morinière E, van der Velde G (1996) Tidal exchange of macrolitter between a mangrove forest and adjacent seagrass beds (Gazi Bay, Kenya). Neth J Aquat Ecol 30:119-128

Slim FJ, Hemminga MA, Ochieng C, Jannick NT, Cocheret de la Morinière $E$, van der Velde G (1997) Leaf litter removal by the snail Terebralia palustris (Linneaus) and sesarmid crabs in an East African mangrove forest (Gazi Bay, Kenya). J Exp Mar Biol Ecol 215:35-48

Thimdee W, Deein G, Sangrungruang C, Matsunaga K (2001) Stable carbon and nitrogen isotopes of mangrove crabs and their food sources in a mangrove-fringed estuary in Thailand. Benthos Res 56:73-80

Vanderklift MA, Ponsard S (2003) Sources of variation in consumer-diet delta N-15 enrichment: a meta-analysis. Oecologia 136:169-182

Submitted: March 23, 2004; Accepted: June 8, 2004

Proofs received from author(s): September 2, 2004 